\title{
Technological aspects of vegetative reproduction of multiple-purpose stock for seeded cultures UUPROZ-6
}

\author{
O. Kishchak,
}

Doctor Agr. Sci.

Institute of Horticulture NAAS of Ukraine

N. Pelekhata,

Cand Agr. Sci.

V.M. Pelekhaty,

Cand Agr. Sci.

Zhytomyr National Agroecological University

The purpose. To develop effective methods of reproduction of multiple-purpose stock for seeded cultures UUPROZ-6 for wide industrial application. Methods. Field, laboratory, statistical. Results. Features of cultivation of this stock by green cuttings and in stock garden are studied, and economic efficiency of its reproduction by the specified methods is fixed. Conclusions. The stock UUPROZ-6 is better for multiplying green cuttings in conditions of artificial fog with the use of water solution of b-indolyloil acid (IOA), or to cultivate in stock garden of horizontal type, using for hilling of semi-rotted pine sawdust and waste ordinary substratum after cultivation of Pleurotus.

Key words: stock UUPROZ-6, green cuttings, layers, substratum for hilling.

Rootstock plays an exceptionally important role in the fruit tree life. The perspective direction of researches in the fruit growing is creation of universal rootstocks for several (three and more) crops. As a rule, such rootstocks are interspecific and intergeneric hybrids. Up to the present time merely universal rootstocks for the stone fruit crops have been spread, while those for the pop crops are not used today. Promise in this connection is the new intergeneric hybrid of quince and apple UUPROZ-6 created in Ukraine.

Our research is based on the scientific papers of I.S. Rudenko, M.V. Matviyenko, P.V. Kondratenko, and V.Y. Chuprynyuk [2, 3, 7, 8]. The investigation has proved this hybrid form compatibility with a number of crops of the apple subfamily and the possibility of using it as a universal vegetative rootstock for the pop crops. Especially valuable this form is for pear as it may get a real alternative to quince rootstocks which are insufficiently frost-resistant and incompatible with many industrial cultivars of this crop.

But the agrotechnological aspects of growing the rootstock material of UUROZ-6 have not been studied sufficiently. There are not enough published papers about the cultivation of the rootstock using the establishment of the parental garden in the vertical way and that in the horizontal way and different substrates for hilling have not been studied hitherto. It is the insufficiency of the UUPROZ-6 vegetative propagation research that determines the actuality of our investigation which may play a considerable role in determining efficient agrotechnical ways of this rootstock propagation using soft wood cuttings and layers.

Purpose of the researches was to elaborate high effective ways of propagating the universal rootstock for pop crops UUPROZ-6 for the extensive manufacturing application.

Materials and methods of the researches. The experiment on the propagation of the rootstock UUPROZ-6 using soft wood cuttings was carried out at the Institute of Horticulture, NAAS (Novosilky, Kyyevo-Svyatoshyn district, the Northern part of the Right-Bank subzone of the Ukraine's Western Lisosteppe) in 2011-2012. A group of rootstocks which had been, entered into the state Register of plant Cultivars Favourable for Dissemination were used as the control in Ukraine, namely: apple 54-118 
(control 1), pear - is 4-6 (control 2). The soft wood cutting was carried out during the active growth of the shoots of the rootstocks in the parental gardens (the first decade of June). For stimulating the root formation the water solution of the $\beta$-indole butiric acid was utilized in concentrations of 0-60 mgl with an exposition of 16 hours (h). The planting plan was $7 \times 5 \mathrm{~cm}$. Each variant contained 35 cuttings in a threefold repetition - 105 plants in all. For rooting the mixture of low peat and granulated river sand was applied in a correlation of 1:1weakly acid reaction (ph of the water extract was $6.0-6.2$ ). The plants management was accepted.

The experiment on the universal rootstock UUPROZ-6 in the layer parental garden was conducted in the botanical garden of the Zhytomyr National Agroecological University ( Zhytomyr, the South of the Ukraine's Western Polissya) during 2011-2014. The soil of the experimental plot was medium loamy meadow chernozem on loess like loams. Soil waters were on a depth of $2-2.5 \mathrm{~m}$. The planting plan envisaged two ways of the layer parental garden establishment (vertical and horizontal) and the use of organic substrates for hilling: half-rotten pine saw-dust, substrate worked waste after growing Pleurotus ostreatus on the basis of the sunflower shell and low peat. Like in the experiment on soft wood cuttings the apple rootstock 54-118 and that of pear IS 4-6 were used as a control.

The clonal rootstocks parental garden was established in April 2011. The planting plan of layers was $1.4 \times 0.25 \mathrm{~m}$ if the parental garden was established in the vertical way and $1.4 \times 0.33 \mathrm{~m}$ when the horizontal way was put to use. The repetition was fourfold; the plots were placed at random.

The plantations management, registrations, observations and estimation of the rootstocks cultivation economic efficiency were carried out using the accepted methods $[4,5,9,10]$.

The rootstocks market quality was determined after the separation of the layers according to the State Standard of Ukraine 4791:2007 «Fruit crops rootstocks. Methods of the quality determination » [6].

The statistic processing of the data were conducted with the usage of the disperse analysis (Dospyekhov B.O.) [1] and computer programs.

Results. The most valuable economic and biological sign of the clonal rootstocks is their ability of rooting. The effective way of the vegetative propagation is soft wood cutting with the application of growth stimulators. In the absence of the rootgenesis stimulator the rootstocks soft wood cuttings rooting was weak - from 19-22\% (IS 4-6 and UUPROZ-6) to $29 \%$ (54-118).

The universal rootstock UUPROZ-6 appeared not to be inferior to the control ones - 54-118 and IS 46 concerning the yield of the rooted soft wood cuttings. The concentrations of the $\beta$-indole butyric acid for treating the cuttings of UUPROZ-6 before planting in the hothouse equipped with the fog generator were $30-50 \mathrm{mg} / \mathrm{l}$ under an exposition of $16 \mathrm{~h}$. In such conditions approximately $88 \%$ of the planted cuttings were rooted. They had about 15 main roots with a summary length of $260 \mathrm{~cm}$. The decrease of the IBA concentration to $10-20 \mathrm{mg} / \mathrm{l}$ or its increase to $60 \mathrm{mg} / \mathrm{l}$ did not contribute to the rooting improvement and to the yield of the UUPROZ-6 soft wood cuttings (table 1).

Table 1. Indices of the clonal rootstocks soft wood cuttings rooting depending on the IBA concentration, average for 2011-2012

\begin{tabular}{|l|l|l|l|l|l|}
\hline $\begin{array}{l}\text { IBA } \\
\text { concentration } \\
\text { mg/l (factor B) }\end{array}$ & $\begin{array}{l}\text { Cuttings } \\
\text { rooting, } \%\end{array}$ & $\begin{array}{l}\text { Roots } \\
\text { amount }\end{array}$ & $\begin{array}{l}\text { Root average } \\
\text { length, cm }\end{array}$ & $\begin{array}{l}\text { Roots } \\
\text { summary } \\
\text { length, cm }\end{array}$ & $\begin{array}{l}\text { Root } \\
\text { increase, cm }\end{array}$ \\
\hline $54-118$ (control 1) (factor A) & \multicolumn{5}{|l|}{} \\
\hline 0 (control) & 29,1 & 10,2 & 4,0 & 41,5 & 1,6 \\
\hline 10 & 79,9 & 14,5 & 7,5 & 109,0 & 7,3 \\
\hline 20 & 98,1 & 27,8 & 12,2 & 339,4 & 15,2 \\
\hline 30 & 100,0 & 39,3 & 13,6 & 535,4 & 16,5 \\
\hline 40 & 99,5 & 28,1 & 11,3 & 318,3 & 15,9 \\
\hline 50 & 91,9 & 20,4 & 11,0 & 224,4 & 14,1 \\
\hline 60 & 87,2 & 12,0 & 9,5 & 114,3 & 12,4 \\
\hline
\end{tabular}




\begin{tabular}{|l|l|l|l|l|l|}
\hline \multicolumn{5}{|l|}{ IS 4-6 (control 2) } & \multicolumn{7}{l|}{$\mid$} \\
\hline 0 (control) & 22,0 & 4,3 & 5,6 & 24,1 & 0,7 \\
\hline 10 & 72,9 & 13,8 & 8,3 & 116,3 & 23,8 \\
\hline 20 & 76,2 & 17,2 & 9,3 & 162,0 & 30,2 \\
\hline 30 & 81,0 & 20,1 & 14,5 & 295,2 & 34,4 \\
\hline 40 & 92,9 & 24,5 & 15,2 & 377,2 & 41,3 \\
\hline 50 & 89,6 & 18,2 & 13,7 & 250,0 & 38,5 \\
\hline 60 & 80,3 & 16,3 & 10,1 & 166,1 & 26,1 \\
\hline UUPROZ-6 & 19,1 & 3,5 & 6,4 & 22,4 & 0,5 \\
\hline 0 (control) & 61,0 & 7,2 & 9,6 & 69,1 & 8,6 \\
\hline 10 & 69,1 & 8,1 & 10,7 & 86,6 & 15,4 \\
\hline 20 & 78,4 & 12,8 & 17,1 & 219,3 & 19,0 \\
\hline 30 & 88,0 & 14,6 & 17,8 & 260,4 & 28,2 \\
\hline 40 & 84,7 & 9,3 & 16,5 & 154,3 & 24,7 \\
\hline 50 & 74,3 & 5,7 & 15,2 & 87,2 & 10,2 \\
\hline 60 & 1,53 & 0,48 & 0,50 & 13,74 & 0,92 \\
\hline LSD 05 A & 2,34 & 0,74 & 0,76 & 20,98 & 1,40 \\
\hline LSD 05 B & 4,05 & 1,28 & 1,31 & 36,34 & 2,43 \\
\hline LSD 05 AB & & & & \\
\hline
\end{tabular}

The researches showed that the biometric parameters of the above ground part of the UUPROZ-6 layers depended on the way of the parental garden establishment and on the substrate for hilling under the horizontal way the rootstock layers growth weakened: the roostockt diameter reduced by $9-13 \%$, and the height by $9-18 \%$. This rootstock hilling with half rotten pine sawdust and worked waste substrate on the basis of the sunflower shell after growing Pleurotus ostreatus by $2-7 \%$ increased the layers thickness and height when establishing the parental garden in the horizontal way. The use of the low peat for the UUPROZ-6 layers hilling decreased all the rootstock biometric indicators. The positive technological characteristics of the mentioned rootstock in the parental garden is full absence of lateral branchings on layers.

The researches in the layer parental garden showed that the UUPROZ-6 growth intensity depended, first of all, on the stands establishment way. The horizontal distribution of the shoots formation wood caused the reduction of the apical and lateral activity. Under the horizontal establishment way the layers were lower by $14 \%$ and thinner by $11 \%$. The factor «substrate for hilling» influenced the UUPROZ- 6 layers growth less substantially.

The longevity of the period since the first hilling till the beginning of the investigated rootstock layers root formation was 36 days on an average. The shoots formation wood horizontal placement combined with hilling with sawdust fungous substrate made it possible to decrease this period by 5 days.

The use of sawdust and fungous substrate also enabled to increase essentially the roots amount and length, the roots summary length on one layer increasing by $111-115 \%$ when utilizing sawdust and by $86-$ $90 \%$ when fungous substrate was put to use.

Concerning the productivity in the layer parental garden UUPROZ-6 was inferior to the rootstock 54118 but exceeded IS 4-6. The highest summary yield of the researched rootstock standard layers in the first 3 productive years was achieved in the parental garden with the roots formation wood horizontal distribution while hilling shoots with substrate worked waste after growing Pleurotus ostreatus and with half rotten pine sawdust -264 and 253 thousand respectively, that is by $53-60 \%$ more than when using ground, the standard layers being $67 \%$ of the total amount, including $33-35 \%$ of those of the first grade and $32-34 \%$ of the second grade (table 2 ). 
Table 2. Productivity of the clonal rootstocks parental garden and layers quality, average for 2012-2014. Planted in 2011

\begin{tabular}{|c|c|c|c|c|c|c|c|}
\hline \multirow{3}{*}{$\begin{array}{l}\text { Rootstock } \\
\text { (factor A) }\end{array}$} & \multirow{3}{*}{$\begin{array}{l}\text { Establishment } \\
\text { way } \\
\text { (factor B) }\end{array}$} & \multirow{3}{*}{$\begin{array}{l}\text { Hilling } \\
\text { substrate } \\
\text { (factor C) }\end{array}$} & \multirow{3}{*}{$\begin{array}{l}\text { Layers } \\
\text { total yield } \\
\text { per } \\
1 \\
\text { thousand }\end{array}$} & \multirow{3}{*}{$\begin{array}{l}\text { Standard } \\
\text { layers } \\
\text { yield per } \\
1 \text { ha, } \\
\text { thousand }\end{array}$} & \multicolumn{3}{|c|}{$\begin{array}{l}\text { Layers marketable } \\
\text { quality, } \% \text { of the total } \\
\text { amount }\end{array}$} \\
\hline & & & & & \multirow{2}{*}{$\begin{array}{l}\text { stan- } \\
\text { dart }\end{array}$} & \multicolumn{2}{|c|}{ including } \\
\hline & & & & & & $\begin{array}{l}1 \\
\text { grade }\end{array}$ & $\begin{array}{l}2 \\
\text { grade }\end{array}$ \\
\hline \multirow{8}{*}{$\begin{array}{l}54-118 \\
\left.\text { (c. }{ }^{*} 1\right)\end{array}$} & \multirow{4}{*}{ Vertical (c.) } & Ground (c.) & 478 & 298 & 65,9 & 53,8 & 12,2 \\
\hline & & Sawdust & 574 & 425 & 78,4 & 64,5 & 13,8 \\
\hline & & Peat & 482 & 315 & 70,0 & 54,6 & 15,4 \\
\hline & & Fungous & 558 & 408 & 75,9 & 62,2 & 13,7 \\
\hline & \multirow{4}{*}{ Horizontal } & Ground (c.) & 524 & 340,5 & 69,6 & 55,7 & 13,9 \\
\hline & & Sawdust & 586 & 459 & 82,0 & 67,0 & 15,0 \\
\hline & & Peat & 501 & 353 & 73,9 & 57,7 & 16,3 \\
\hline & & Fungous & 579 & 445 & 79,5 & 65,0 & 14,5 \\
\hline \multirow{8}{*}{$\begin{array}{l}\text { IC 4-6 } \\
\text { (c. } 2 \text { ) }\end{array}$} & \multirow{4}{*}{ Vertical (c.) } & Ground (c.) & 761 & 337 & 55,7 & 19,8 & 36,0 \\
\hline & & Sawdust & 756 & 339 & 55,6 & 19,5 & 36,1 \\
\hline & & Peat & 826 & 396 & 58,6 & 21,2 & 37,4 \\
\hline & & Fungous & 796 & 402 & 61,4 & 23,1 & 38,3 \\
\hline & \multirow{4}{*}{ Horizontal } & Ground (c.) & 746 & 270 & 43,1 & 7,4 & 35,7 \\
\hline & & Sawdust & 744 & 261 & 41,8 & 7,8 & 34,0 \\
\hline & & Peat & 801 & 334 & 46,8 & 9,0 & 37,8 \\
\hline & & Fungous & 770 & 335 & 49,6 & 10,3 & 39,3 \\
\hline \multirow{8}{*}{ UUPROZ-6 } & \multirow{4}{*}{ Vertical (c.) } & Ground (c.) & 316 & 165 & 56,7 & 31,1 & 25,6 \\
\hline & & Sawdust & 358 & 214 & 64,7 & 42,3 & 22,3 \\
\hline & & Peat & 312 & 168 & 57,7 & 32,7 & 25,0 \\
\hline & & Fungous & 374 & 216 & 62,4 & 39,7 & 22,7 \\
\hline & \multirow{4}{*}{ Horizontal } & Ground (c.) & 362 & 200 & 58,2 & 24,9 & 33,3 \\
\hline & & Sawdust & 412 & 253 & 66,9 & 35,0 & 31,9 \\
\hline & & Peat & 337 & 194 & 58,7 & 24,1 & 34,6 \\
\hline & & Fungous & 431 & 264 & 66,6 & 32,7 & 33,8 \\
\hline \multicolumn{3}{|l|}{$L S D_{05} A$} & 23,4 & 15,2 & - & - & - \\
\hline \multicolumn{3}{|l|}{$L S D_{05} B$} & 19,1 & 12,4 & - & - & - \\
\hline \multicolumn{3}{|l|}{$L S D_{05} C$} & 27,1 & 17,6 & - & - & - \\
\hline \multicolumn{3}{|l|}{$L S D_{05} A B$} & 33,2 & 21,5 & - & - & - \\
\hline \multicolumn{3}{|l|}{$L S D_{05} A C$} & 46,9 & 30,5 & - & - & - \\
\hline \multicolumn{3}{|l|}{$L S D_{05} B C$} & 38,3 & 24,9 & - & - & - \\
\hline \multicolumn{3}{|l|}{$L S D_{05} A B C$} & 66,1 & 43,0 & - & - & - \\
\hline
\end{tabular}

The economic estimation of the efficiency of the propagation of the clonal rootstocks with using soft wood cuttings has shown that the optimum IBA concentration for the UUPROZ-6 soft wood cutting is 40$50 \mathrm{mg} / \mathrm{l}$ with an exposition of 16 hours that enables to gain a profit of $315-349 \mathrm{grn} . / \mathrm{m}^{2}$ under a profitableness level of 224-251 \%. The both control rootstocks had the lower production profitableness not higher than $145-154 \%(54-118)$ and $154-182 \%$ (IS 4-6) in the best variants (table 3). 
Table 3. Economic efficiency of the rootstocks UUPROZ-6 propagation with the use of softwood cutlings, average for 2011-2012

\begin{tabular}{|l|l|l|l|l|l|l|l|}
\hline \multirow{2}{*}{ Index } & \multicolumn{2}{|l|}{ IBA concentration, mg/l } \\
\cline { 2 - 9 } & $\mathbf{0}$ & $\mathbf{1 0}$ & $\mathbf{2 0}$ & $\mathbf{3 0}$ & $\mathbf{4 0}$ & $\mathbf{5 0}$ & $\mathbf{6 0}$ \\
\hline $\begin{array}{l}\text { Rooted cuttings yield per } \\
1 \mathrm{~m}^{2}\end{array}$ & 26 & 152 & 179 & 202 & 244 & 228 & 183 \\
\hline Products cost, grn./ m2 & 52 & 304 & 259 & 405 & 488 & 455 & 367 \\
\hline $\begin{array}{l}\text { Productional expenditures, } \\
\text { grn./ m }\end{array}$ & 132 & 134 & 136 & 137 & 139 & 141 & 142 \\
\hline $\begin{array}{l}\text { Production cost of } \\
1 \text { rootstocks, grn. }\end{array}$ & 5,10 & 0,88 & 0,76 & 0,68 & 0,57 & 0,62 & 0,78 \\
\hline Profit, grn./m m & -81 & 170 & 223 & 267 & 349 & 315 & 224 \\
\hline Profitableness, \% & -61 & 127 & 164 & 194 & 251 & 224 & 157 \\
\hline
\end{tabular}

As to the layer parental garden the researches have proved that it is the most economically efficient to establish the rootstocks UUPROZ-6 stands with the horizontal distribution of the shoot formation wood and to use for hilling half rotten pine sawdust and substrate worked waste after growing Pleurotus ostreatus (table 4). It provides gaining the profit 219-235 thousand grn./ha under the profitableness level $319-368 \%$. The economic efficiency of the control rootstocks $54-118$ and IS 4-6 layers growing in the best variants was at the UUPROZ-6 level.

Table 4. Economic efficiency of the rootstock UUPROZ-6 propagation using layers, average for 2011-2012

\begin{tabular}{|c|c|c|c|c|c|c|c|c|}
\hline \multirow{3}{*}{ Indicator } & \multicolumn{8}{|c|}{ Ways of the parental garden establishment } \\
\hline & \multicolumn{4}{|l|}{ vertical } & \multicolumn{4}{|c|}{ horizontal } \\
\hline & Ground & Sawdust & Peat & WWS $^{1}$ & Ground & Sawdust & Peat & WWS1 \\
\hline $\begin{array}{l}\text { Standard layers } \\
\text { yield per } 1 \text { ha }\end{array}$ & 54,9 & 71,2 & 55,8 & 71,8 & 66,6 & 84,3 & 64,7 & 87,9 \\
\hline $\begin{array}{l}\text { Products cost, } \\
\text { thousand grn./ha }\end{array}$ & 191 & 255 & 195 & 256 & 222 & 288 & 214 & 299 \\
\hline $\begin{array}{l}\text { Productional } \\
\text { expenditures } \\
\text { thousand grn./ha }\end{array}$ & 62,5 & 77,9 & 86,9 & 72,8 & 52,4 & 67,9 & 76,5 & 62,9 \\
\hline $\begin{array}{l}\text { Production cost of } \\
1 \text { thousand } \\
\text { standard layers, } \\
\text { grn. }\end{array}$ & 1148 & 1104 & 1567 & 1024 & 797 & 815 & 1193 & 726 \\
\hline $\begin{array}{l}\text { Profit, thousand } \\
\text { grn./ha }\end{array}$ & 128 & 176 & 107 & 182 & 169 & 219 & 136 & 235 \\
\hline Profitableness, \% & 203 & 224 & 123 & 248 & 318 & 319 & 177 & 368 \\
\hline
\end{tabular}

WWS is worked waste substrate.

\section{Conclusions}

High effective methods of the propagation of UUPROZ-6 - the universal pop crops rootstocks are recommended for the wide productional test. The propagation should be carried out under the conditions of the fog generator using softwood cuttings and the water solution of the $\beta$-indole butyric acid in concentrations of $30-50 \mathrm{mg} / \mathrm{l}$ as well as by means of establishing layer parental gardens in the horizontal way utilizing half rotten pine sawdust and substrate worked waste after growing Pleurotus ostreatus for the hilling of vegetating layers. 


\section{References}

1. Dospyekhov B.A. Metodyka polyevogo opyta / B.A. Dospyekhov . - M.: Kolos, 1985. - 351 c.

2. Kondratenko P.V. UUPROZ-6 - universal'na pidshchepa rosotsvityh /

P.V. Kondratenko, M.V. Matviyenko, V.Ya. Chuprynyuk // Sadivnytstvo. - 2005. - Vyp. 57. - S.177179.

3. Matviyenko M.V. Grusha $\vee$ Ukraini (istoriya, syogodennya, perspectyvy)/ M.V. Matviyenko, R.O. Babina, P.V. Kondratenko.- K:Agrarna nauka, 2006. - 320 s.

4. Metodyka ekonomichnoi ta energetychnoi otsinky typiv nasadzhen', sortiv, investytsii $v$ osnovnyikapital, innovatsii ta resul'tativ tehnologichnyh doslidzhen' u sadivnytstvi za red. O.M. Shestopalia. - K.: HC. UAAN "Plodivnitstvo", 2006. - $140 \mathrm{~s}$.

5. Myetodika izuchyeniya podvoyev plodovyh kyl'tur v Ukrainskoi SSR / Red. M.V. Andriyenko, I.P. Gulko. - K.: UAAN-UNIIS, 1990. - 104 s.

6. Pidshchepy plodovyh kyl tur. Myetodika vyznacheniya yakosty: DSTU 479: 2007. - [Chynyi vid 2009-01-01]. - K.: Derzhspozhyvstandart Ukraine, 2008. - 15 s. (Derzhavnyi standart Ukrainy ).

7. Rudenko I.S. Hybridizatciya yabluni s ayvoi / I.S. Rudenko. - Kyshiniyov: Kartya Moldoveniyaske, 1969. $-63 \mathrm{~s}$.

8. Rudenko I.S. Otdalionnaya hybridizatsia I poliploidia u plodovyh rasteniy / I.S. Rudenko. Kyshiniyov: Shtointsa, 1978. - $196 \mathrm{~s}$.

9. Typovi tehnologichni karty vyroshchuvannya sadyvnogo materialu plodovyh ta yagidnyh kultur za redakaiya O.Yu. Yermakova. - K.: Institut agrarnoi economiky, 2002. - 70 s.

10. Uchyoty, nablyudyeniya, analizy, obrabotka dannyh $v$ opytah $\mathrm{s}$ plodovymi i yagodnymi rastyeniyami. Metody. Recomendatsii / Pod red. G.K. Karpenchuka, A.V. Melnica. - Uman, 1987. - 115 s. 